\title{
PAUL RICOEUR E A FILOSOFIA DA RELIGIÃO ${ }^{1}$
}

\section{Paul Ricoeur and the Philosophy of Religion}

Thiago Luiz de Sousa ${ }^{2}$

Resumo: Paul Ricoeur (1913-2005) é um dos mais importantes filósofos contemporâneos e nunca deixou de afirmar que, mesmo sendo filósofo, era crente. Sendo assim, a obra de tal autor é um lugar privilegiado para o estudo da temática religiosa. Deste modo, o presente artigo pretende apresentar quais são as bases da filosofia da religião de Paul Ricoeur e avaliar sua originalidade. Cremos que se a originalidade da hermenêutica filosófica se dá por meio de sua reflexividade, do mesmo modo se dará sua originalidade no campo da filosofia da religião.

Palavras-chave: Paul Ricoeur; Filosofia da Religião, Reflexividade;

Abstract: Paul Ricoeur (1913-2005) is one of the most important contemporary philosophers and he never failed to state that he was religious even though he was a philosopher. Thus, the work of such an author is remarkable in terms of the study of religious themes. Therefore, the present article intends to present the foundations of Paul Ricoeur's philosophy of religion and evaluate its originality. We believe that if the originality of philosophical hermeneutics occurs through its reflexivity, so will its originality in the field of philosophy of religion.

Keywords: Paul Ricoeur; Philosophy of Religion; Reflexivity;

\footnotetext{
${ }^{1}$ Trata-se de uma revisão de nossa dissertação de mestrado, O estatuto de uma Hermenêutica Filosófica e seu enriquecimento para a Hermenêutica Bíblica em Paul Ricoeur.

${ }^{2}$ Bacharel em Filosofia e Mestre em Ciência da Religião pela Universidade Federal de Juiz de Fora (UFJF). Atualmente está no doutorado em Filosofia da Universidade Federal de Minas Gerais (UFMG). E-mail: thiagoluiz-sousa@hotmail.com
} 
Quando o assunto é filosofia da religião, o próprio Ricoeur admite que Kant é o seu autor preferido (RICOEUR, 1995, p. 202). Um dos textos do filósofo francês, que é em homenagem ao padre Claude Geffré, reflete justamente sobre este tema no filósofo alemão. Tal texto pode ser encontrado em sua versão inglesa na obra Figuring The Sacred: Religion, Narrative, and Imagination, sob o título A Philosophical Hermeneutics of Religion: Kant, e em português na obra Leituras 3: Nas Fronteiras da Filosofia, sob o título Uma hermenêutica filosófica da religião: Kant. Neste texto sobre Kant, encontramos a análise daquilo que o próprio Ricoeur considera ser uma "hermenêutica filosófica da religião" (RICOEUR, 1996b, p. 19).

O texto kantiano que é base para a análise ricoeuriana é A religião nos limites da simples razão e é considerado por Ricoeur como uma hermenêutica filosófica da religião por três motivos: primeiro, Kant não tem como objeto de investigação Deus, mas a religião. O filósofo alemão trata este tema sob um triplo aspecto, representação, crença e instituição (RICOEUR, 1996b, p. 19). Em A experiência religiosa: Essência, valor e verdade, Carlo Grego enfatiza este mesmo ponto na constituição de uma filosofia da religião:

O objeto da filosofia da religião não é imediatamente Deus nem a demonstração de sua existência, mas sim a relação do homem com Deus: a religião. Tal objeto, enquanto fato histórico cultural inegável e experiência humana difusa, pode ser investigado e estudado por intermédio de suas objetivações (mitos, símbolos, ritos) (GRECO, 2009, p. 29).

O segundo motivo apontado por Ricoeur é o estatuto da liberdade pressuposta por Kant. Segundo o filósofo francês, "O que põe toda a obra em movimento é a situação de fato do livre-arbítrio (Willkür), do poder de escolher entre a obediência à lei do desejo empírico" (RICOEUR, 1996b, p. 20). O grande enigma que é gérmen de toda filosofia da religião é justamente como este livre arbítrio se torna um "servo arbítrio", no sujeito religioso. Greco também fala sobre este enigma, ao comentar os escritos de Rizzi: 
O emergir do horizonte escatológico abre o homem para liberdade "radical", que se afirma em contraste com a tendência espontânea do eu. De fato, segundo Rizzi, o horizonte natural da vida do homem é o desejo, isto é, a tendência a expandir-se para realizar-se, impulso essencial e inconscientemente egocêntrico (não egoísta) que nos leva a buscar a nós mesmos em tudo quanto realizamos, tocamos, amamos. Pois bem, a aparição do apelo moral (do "deve") dissocia o eu da solidariedade essencial consigo mesmo, torna-o independente do dinamismo narcisista que o anima e o alimenta. No espaço escatológico do espírito, o imperativo moral apresenta-se como alternativa à espontaneidade. Liberdade em sentido "radical" é aqui a escolha entre o eu e o imperativo, no horizonte último da existência (GRECO, 2009, p. 191).

Esta liberdade que reconcilia o sujeito com o imperativo é a tarefa da religião. Tal tarefa nos direciona para uma problemática, a problemática do mal. Esta problemática é fundamental de ser lembrada, pois

[...] o mal é o ponto crítico de todo pensamento filosófico: se ele o compreende, este é o seu maior sucesso; mas o mal compreendido não é mais o mal, ele deixou de ser absurdo, escandaloso; à margem do direito e da razão. Se não o compreende, então a filosofia não é filosofia, se é verdade que a filosofia deve tudo compreender e se erigir em sistema, sem resto fora dele, (RICOEUR, 1996a, p. 16).

Assim, em última análise, o ponto crítico da filosofia da religião é o ponto crítico da filosofia em um sentido geral. Como podemos ver, o problema do mal não pode encerrar-se com a filosofia, uma vez que o mal compreendido já não é o mal. Neste sentido, devemos observar outra área, além da filosofia, que também enfrenta esta problemática, a teologia. O teólogo deve enfrentar o mal a partir da seguinte questão: "(como se pode afirmar conjuntamente, sem contradição, as três preposições seguintes): Deus é todo poderoso; Deus é absolutamente bom; contudo, o mal existe" (RICOEUR, 1996b, p. 21). Sendo assim, podemos dizer que a filosofia deve levar em conta o escândalo do mal, enquanto a teologia busca compreender a possibilidade do mal perante a existência de um Deus que seja bom. Já a filosofia da religião está entre estas duas realidades, uma vez que questiona: como o sujeito pode superar, através de sua liberdade, o mal? Por isso, Ricoeur afirma: “[ [...] um dos motivos maiores da hermenêutica filosófica da religião é dar a razão, nos limites da simples razão, 
desse entrecruzamento entre o reconhecimento do mal radical e a assunção dos meios de regeneração” (RICOEUR, 1996b, p. 21).

Por fim, o terceiro motivo para considerar este texto kantiano como hermenêutica filosófica da religião é a articulação entre a problemática do mal e a religião em sua tripla temática, representação s crença e instituição. O ponto principal desta articulação se dá na investigação do quanto essas temáticas são canais de restauração para o sujeito (RICOEUR, 1996b, p. 22). Com isso, podemos dizer que a hermenêutica filosófica da religião tem sempre uma função restauradora, isto é, sempre é fonte de esperança. Assim comenta Greco:

Com outras palavras, trata-se de verificar a possibilidade de uma hermenêutica restauradora do sentido da experiência religiosa que, em se movendo "na aragem do sentido interrogado" (Ricoeur), esteja apta a reconhecer o alcance revelador e ontológico dos símbolos do Sagrado e de experimentá-lo conceitualmente. [...] Toda religião é oferta de salvação, isto é, libertação do mal na multiplicidade de suas formas e figuras, e, por essa razão, é portadora e, ao mesmo tempo, testemunha de um saber existencial e salvífico (GRECO, 2009, p. 176).

Dados tais motivos, interessa-nos as conclusões que Ricoeur tira com a análise destes. São três conclusões que ele apresenta:

1) A filosofia necessita da filosofia da religião por causa da problemática do mal. Ora, é necessária uma hermenêutica, isto é, uma filosofia que investigue o mal e suas próprias complexidades, sem reduzi-lo. O mal investigado pela filosofia da religião é o mal da própria religião, ou seja, a religião desenvolve pensamentos acerca desta temática que a filosofia por si só não poderia desenvolver.

2) A filosofia da religião é possível por conta da afinidade de algumas temáticas tratadas tanto pela filosofia, quanto pela teologia. Um destas problemáticas seria o mal.

3) A filosofia da religião não é uma extensão da filosofia, mas ela é atópica, por conta de sua temática própria: "ela dá corpo a uma inteligência da esperança enquanto réplica de um gênero único ao reconhecimento do mal radical” 
(RICOEUR, 1996b, p. 40). Ou seja, a filosofia da religião não seria uma extensão da própria da filosofia por ter que contar com uma espécie de pensamento que não argumenta, o pensamento religioso, enquanto $o$ pensamento filosófico é estritamente argumentativo.

Diante destes pontos, questionamos: qual seria a contribuição original de Ricoeur para esta área? Ou melhor, qual seria a contribuição original de Ricoeur para filosofia da religião? É isto que tentaremos aqui responder.

\section{II}

Primeiramente, para respondermos tal questionamento, devemos demarcar os limites tanto do discurso filosófico, quanto do discurso da filosofia da religião. Para isto, um bom caminho é através da temática do amor, ou melhor, da dialética entre o amor e a justiça. Por isso, o ensaio Amor e Justiça é de suma importância para nossa investigação. Paul Ricoeur inicia o seu ensaio com a seguinte fala:

Falar do amor é fácil demais ou difícil demais. Como não cair na exaltação ou nas platitudes emocionais? Uma maneira de abrir caminho entre esses dois extremos é tomar como guia um pensamento que medite a dialética entre amor e justiça. Por dialética entendo aqui, de um lado, o reconhecimento da desproporção inicial entre os dois termos e, de outro lado, a busca das mediações práticas entre os dois extremos - mediações, digamos desde já, sempre frágeis e provisórias (RICOEUR, 2012a, p. 3).

É esta desproporção inicial que Ricoeur aponta que nos interessa. Comecemos com o discurso da justiça. Paul Ricoeur considera a justiça em dois níveis: (i) no nível da prática social, que se identifica tanto com o aparelho judiciário, quanto com o estado de direito; e (ii) com os princípios de justiça, aqueles que regem as instituições (RICOEUR, 2012a, p. 16). O primeiro nível, o da prática, nos revela que a justiça é parte de uma atividade que é comunicacional, isto é, para a força pública aplicar a justiça ela necessita se comunicar, argumentar: 
A justiça argumenta, e de uma forma muito particular, confrontando razões pró ou contra, supostamente plausíveis, comunicáveis, dignas de serem discutidas pela outra parte. Dizer, como sugeri acima, que a justiça é uma parte da atividade comunicacional adquire aqui todo o seu sentido: o confronto entre o argumento diante de um tribunal é um exemplo notável de emprego dialógico da linguagem (RICOEUR, 2012a, p. 17).

No segundo nível, o dos princípios de justiça, Ricoeur discorre sobre a relação entre igualdade e justiça. Segundo nosso autor, Aristóteles foi o primeiro autor a notar a dificuldade do tratamento igualitário entre pessoas com diferentes bens, propriedades, entre outros. John Rawls retoma este problema e pede "[...] que o aumento da vantagem do mais favorecido seja compensado pela diminuição da desvantagem do mais desfavorecido" (RICOEUR, 2012a, p. 20). Temos, com isso, uma base moral para prática da justiça:

O conceito de distribuição, considerado em sua extensão máxima, confere uma base moral à pratica social da justiça, tal como caracterizamos acima, como regulação dos conflitos; nela, de fato, a sociedade é vista como um lugar de confronto entre parceiros rivais; a ideia de justiça distributiva abarca todas as operações do aparelho judiciário, dando a elas a finalidade de manter as pretensões de cada um em limites tais que a liberdade de um não comprometa a do outro (RICOEUR, 2012a, p. 21).

O ponto principal a ser notado é que a justiça se dirige à ação, porém esta direção se dá de forma argumentativa e é sustentada por um conceito moral, o da justa distribuição, para que todas as partes possam se comunicar com uma certa igualdade. Observemos, então, o discurso do amor e sua distinção em relação ao discurso da justiça.

Se o discurso da justiça é trabalhado por Ricoeur através de dois pontos marcantes, o discurso do amor é apresentado sob três pontos marcantes, ou melhor, três pontos marcantes e estranhos ao discurso de justiça. Apresentemos os pontos destacados por Ricoeur:

$1^{\circ}$ ponto: "O discurso do amor é, antes de tudo, um discurso de louvor" (RICOEUR, 2012a, p. 6).

Neste ponto, Ricoeur está reconhecendo duas coisas: primeiro, a ordem distinta ao qual o amor pertence e que Pascal aponta: 
Todos os corpos juntos e todos os espíritos juntos, e todas as produções não equivalem ao menor movimento de caridade. Isso é de uma ordem infinitamente mais elevada. - De todos os corpos juntos não se pode resultar um pequeno pensamento: é impossível, e de outra ordem. De todos os corpos e espíritos, não se pode extrair um movimento de verdadeira caridade, é impossível, e de outra ordem, sobrenatural (PASCAL, apud RICOEUR, 2012a, p. 5).

Com isso, sabemos que "[...] o amor fala, mas numa língua diferente daquela da justiça [...]” (RICOEUR, 2012a, p. 6). Mas, como o amor fala? Esta é a segunda coisa reconhecida, o amor, além de ser de outra ordem, é expresso, antes de tudo, através do louvor. Observemos o texto de São Paulo:

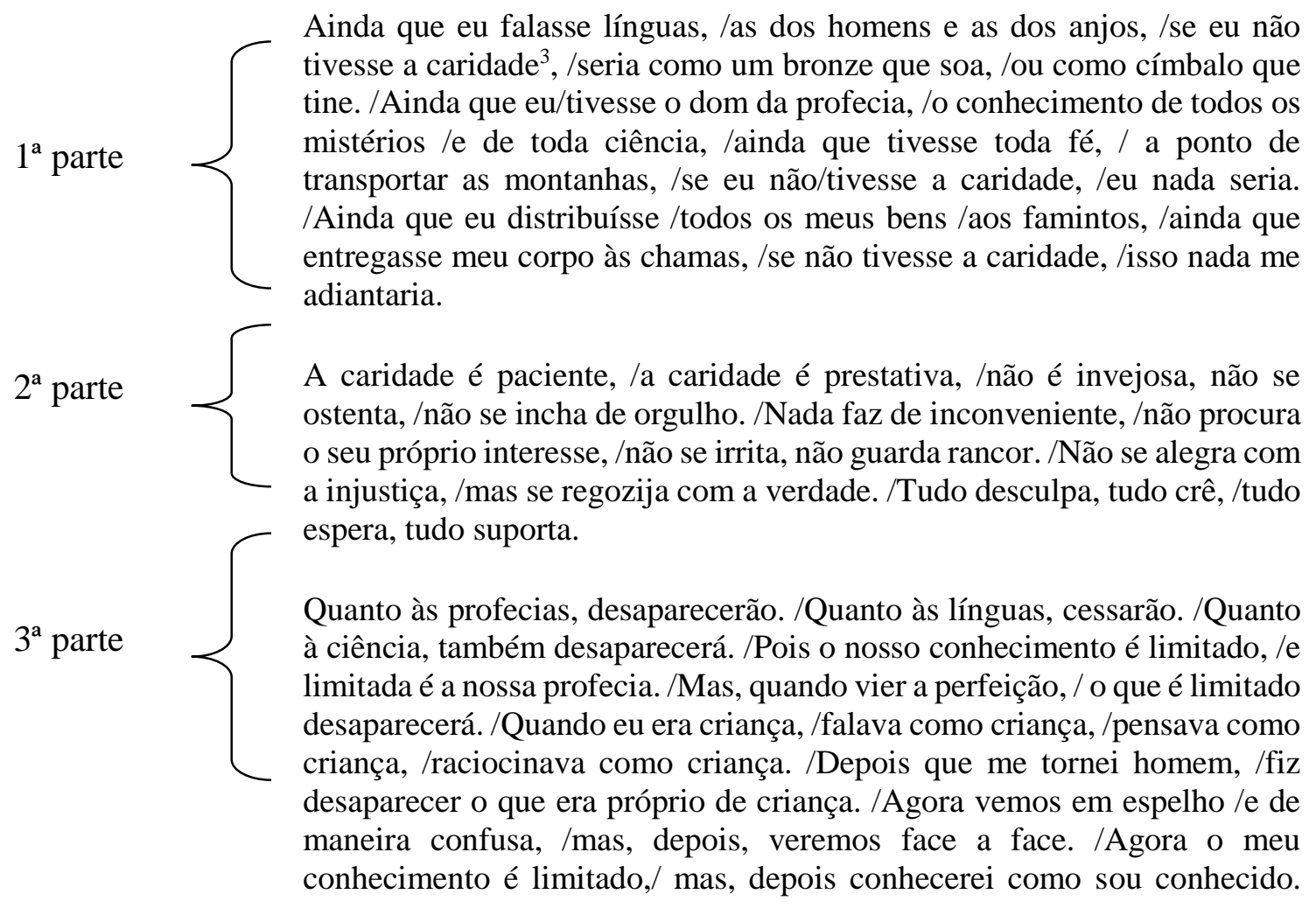

Ainda que eu falasse línguas, /as dos homens e as dos anjos, /se eu não tivesse a caridade ${ }^{3}$, /seria como um bronze que soa, /ou como címbalo que tine. /Ainda que eu/tivesse o dom da profecia, /o conhecimento de todos os mistérios /e de toda ciência, /ainda que tivesse toda fé, / a ponto de transportar as montanhas, /se eu não/tivesse a caridade, /eu nada seria. /Ainda que eu distribuísse /todos os meus bens /aos famintos, /ainda que entregasse meu corpo às chamas, /se não tivesse a caridade, /isso nada me adiantaria.

A caridade é paciente, /a caridade é prestativa, /não é invejosa, não se ostenta, /não se incha de orgulho. /Nada faz de inconveniente, /não procura o seu próprio interesse, /não se irrita, não guarda rancor. /Não se alegra com a injustiça, /mas se regozija com a verdade. /Tudo desculpa, tudo crê, /tudo espera, tudo suporta.

Quanto às profecias, desaparecerão. /Quanto às línguas, cessarão. /Quanto à ciência, também desaparecerá. /Pois o nosso conhecimento é limitado, /e limitada é a nossa profecia. /Mas, quando vier a perfeição, / o que é limitado desaparecerá. /Quando eu era criança, /falava como criança, /pensava como criança, /raciocinava como criança. /Depois que me tornei homem, /fiz desaparecer o que era próprio de criança. /Agora vemos em espelho /e de maneira confusa, /mas, depois, veremos face a face. /Agora o meu conhecimento é limitado,/ mas, depois conhecerei como sou conhecido.

\footnotetext{
${ }^{3}$ A tradução em língua portuguesa da Bíblia da Jerusalém apresenta a caridade como sendo exaltada por São Paulo. Não obstante, outras edições optam em traduzir tal termo por amor. Em todo nosso texto, optamos por utilizar como fonte bíblica a Bíblia de Jerusalém. Nossa preferência se dá a partir da própria preferência de Paul Ricoeur. Em A crítica e a convicção, após citar um versículo bíblico, Ricoeur afirma: "cito a tradução da Bíblia de Jerusalém pela qual tenho um fraquinho" (Ricoeur, 1995, p. 214).
} 
/Agora, portanto, permanecem fé, /esperança, caridade,/ essas três coisas. /A maior delas, porém, é a caridade (BÍBLIA, 1Coríntios 13, 1-13).

Por meio do texto paulino, podemos notar duas coisas: (i) o amor (a caridade) é tratado como poesia, "[...] o amor não argumenta, se tomarmos como modelo o hino de 1 Coríntios 13” (RICOEUR, 2012a, p. 17) e (ii) como toda poesia, “[...] [suas] palavras-chave passam por amplificações de sentido, assimilações inesperadas, interconexões inéditas" (RICOEUR, 2012a, p. 7). Paul Ricoeur indica que esta amplificação se dá no texto paulino em três etapas, como indicamos na separação das partes na citação acima. Na primeira parte, há uma exaltação do amor; na segunda parte, esta elevação é posta como se tudo já estivesse consumado; e, por fim, na terceira parte, esta elevação é elevada acima de todo limite (RICOEUR, 2012a, p. 7-8).

Se identificamos o amor com o discurso poético, estamos a um passo de identificá-lo com os discursos expressos nos Salmos, uma vez que thillin, título dos Salmos em hebraico, seguindo a tradução de Eduardo Brandão, significa “cantos de louvor” (RICOEUR, 2012a, p. 6). Por isso, segundo Ricoeur, podemos aproximar o hino paulino ao seguinte salmo:

Feliz o homem /que não vai ao conselho dos ímpios, /não para no caminho dos pecadores, /nem se assenta na roda dos zombadores. /Pelo contrário: /seu prazer está na lei de Iahweh, /e medita sua lei, dia e noite. /Ele é como árvore/ plantada junto d'agua corrente: /dá fruto no tempo devido /e suas folhas nunca murcham; /tudo o que ele faz é bem sucedido (BÍBLIA, Salmos, 1, 1-3).

Ou a este outro salmo: "Iaweh dos Exércitos, /feliz o homem que em ti confia!" (BÍBLIA, Salmos, 84, 13). Por que isto é importante de ser percebido? Porque é este o mesmo tipo de discurso que aparece nas bem-aventuranças no Novo Testamento, onde fica claro o papel de configuração deste tipo de discurso, por exemplo, “[b]em-aventurados os pobres em espírito, /porque deles é o reino dos céus" (BÍBLIA, Mateus, 5, 3). Estamos perto da segunda estranheza do discurso do amor:

$2^{\circ}$ ponto: $\mathrm{O}$ amor também é visto como imperativo.

Jesus Cristo fala: 
[...] Amarás ao Senhor teu Deus de todo o teu coração, de toda a tua alma e de todo entendimento. Esse é o maior e o primeiro mandamento. $\mathrm{O}$ segundo é semelhante a esse: Amará o teu próximo como a ti mesmo. Desses mandamentos dependem toda a Lei e os Profetas (BÍBLIA, 22, 37-40).

Este mandamento é estranho, pois como erigir um sentimento a um imperativo? Paul Ricoeur vê isto como possibilidade através do auxílio dos escritos de Franz Rosenzweig. A ajuda de Rosenzweig vem através do diálogo íntimo entre Deus e a alma sozinha como base do mandamento do amor. Assim comenta Ricoeur:

A ideia verdadeiramente genial é então mostrar o mandamento de amar jorrando desse vínculo de amor entre Deus e a alma solitária. O mandamento que procede toda lei é a palavra que o amante dirige à amada: ama-me! Essa distinção inesperada entre mandamento e lei só tem sentido se admitirmos que o mandamento de amar é o próprio amor, que se recomenda a si mesmo, como se o genitivo contido no mandamento de amar fosse ao mesmo tempo genitivo objetivo e genitivo subjetivo; o amor é objeto e sujeito do mandamento; em outras palavras, é um mandamento que contém as condições da sua própria obediência pela ternura da sua instância: ama-me (RICOEUR, 2012a, p. 11).

Se todos os mandamentos procedem do mandamento do amor e este provém da relação entre a palavra do amado em direção à amada, entre a relação solitária do sujeito com Deus, os mandamentos que envolveriam um terceiro procedem de uma relação inicial, que é, antes de mais nada, entre um "eu” e um "tu”. Neste sentido, os mandamentos de Cristo, segundo São Mateus, não seriam:

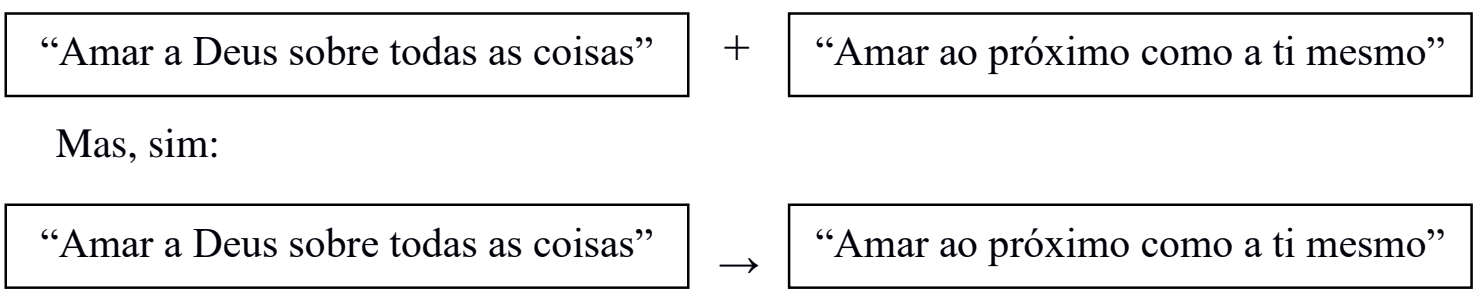

O principal disso se dá na frase final da proclamação destes mandamentos, onde Jesus Cristo afirma: "Desses mandamentos dependem todas as Leis e os Profetas". Neste sentido, até mesmo a regeneração que a religião oferece passa por este foro íntimo. Mas, e o amor enquanto prazer, onde que entra nisso? 
Este é a terceiro ponto: “[...] o poder da metaforização que se prende às expressões do amor" (RICOEUR, 2012a, p. 12).

O ama-me! possui um dinamismo, porque ele é capaz de mobilizar os afetos, desde o prazer até a dor, desde a satisfação até o descontentamento. Um exemplo disso podemos encontrar em um dos sonetos de Luís de Camões:

Amor é um fogo que arde sem se ver, lé ferida que dói, e não se sente; lé um contentamento descontente, lé dor que desatina sem doer. /É um não querer mais que bem querer; lé um andar solitário entre a gente; lé nunca contentar se de contente; /é um cuidar que ganha em se perder. /É querer estar preso por vontade; lé servir a quem vence, o vencedor; lé ter com quem nos mata, lealdade. /Mas como causar pode seu favor /nos corações humanos amizade, /se tão contrário a si é o mesmo Amor? (CAMÕES, 2018, n.p).

É a imagem de um campo de gravitação, de um espiral ascendente e descendente, “contentamento descontente", "dor que desatina sem doer", corresponde, assim, no plano da linguagem ao que acaba de ser designado acima como processo de metaforização. É graças a ele que o amor erótico é capaz de significar mais que ele mesmo e visar indiretamente outras qualidades que não o amor (RICOEUR, 2012a, p. 14-15). Se o amor é capaz de significar algo além, é por conta das expressões fornecidas pelo amor erótico.

De um lado, o discurso da justiça. De outro lado, o discurso do amor. De um lado, um discurso que argumenta. De outro lado, um discurso que vai além de toda argumentação, que nasce de uma relação íntima e que só é possível se expressar poeticamente. O que estes discursos têm em comum? Os dois se voltam para ação. Ou melhor, os dois se encontram na ação. Paul Ricoeur vê no texto de São Lucas uma reflexão sobre este encontro:

Eu, porém, vos digo a vós que me escutais: Amai os vossos inimigos, fazei bem aos que vos odeiam, bendizei os que vos amaldiçoam, orai por aqueles que vos difamam. A quem te ferir numa face, oferece a outra; a que te arrebatar a capa, não recuseis a túnica. Dá a quem te pedir e não reclames de quem tomar o que é teu Como quereis que os outros façam, fazei também a eles. Se amais os que vos amam, que graças alcançais? Pois até mesmo os pecadores amam aqueles que os amam. E se fazeis o bem aos que vo-lo fazem, que graça alcançais? Até mesmo os pecadores emprestam aos 
pecadores para receberem o equivalente. Muito pelo contrário, amai vossos inimigos, fazei o bem e emprestai sem esperar coisa alguma em troca. Será grande vossa recompensa, e sereis filhos do Altíssimo, pois ele é bom para com os ingratos e com os maus (BÍBLIA, Lucas 6, 27-35).

Neste trecho bíblico, segundo Ricoeur, podemos ver a reflexão sobre duas lógicas, a lógica da equivalência, do discurso da justiça, e a lógica da superabundância, o discurso do amor. O que é necessário perceber é que o discurso do amor não abole o discurso da justiça, mas o reinterpreta:

[...] o mandamento de amor não abole a Regra de Ouro, mas a reinterpretação no sentido da generosidade e, assim, faz dela um canal não apenas possível mas necessário de um mandamento que, em razão do seu estatuto supraético, só alcança a esfera ética à custa de comportamentos paradoxais e extremos, os mesmo que são recomendados na esteira do novo mandamento [...] (RICOEUR, 2012a, p. 29).

Neste sentido, o discurso ético, o da justiça, o da lógica da equivalência, não pode ser colocado de lado. Pelo contrário, tal discurso é condição de possibilidade do discurso do amor, só assim o amor consegue sua extravagância, que faz com que envolva os afetos, destacados na terceira estranheza deste discurso. Além disso, o discurso do amor tem um papel muito importante perante o discurso da justiça, um papel corretivo:

[...] nessa relação de tensão viva entre lógica de superabundância e a lógica da equivalência, esta última recebe de seu confronto com a primeira a capacidade de se elevar acima das suas interpretações perversas. De fato, sem o corretivo do mandamento de amor, a Regra de Ouro seria incessantemente puxada no sentido de uma máxima utilitária cuja fórmula do ut des, dou para que dês. A regra dá porque te deram, corrige o a fim de que da máxima utilitária e salva a Regra de Ouro de uma interpretação perversa sempre possível. É nesse sentido que podemos interpretar a presença das duras palavras de Lucas 6, 32-34, logo depois da reafirmação da Regra de Ouro em 6, 31 e logo antes da reafirmação do novo mandamento em 6, 35 (RICOEUR, 2012a, p. 30).

Sendo assim, conseguimos compreender o papel que o discurso do amor exerce sobre o discurso da justiça, que seria análogo ao papel do discurso religioso ao discurso filosófico. A conclusão do ensaio Amor e Justiça segue esta direção: 
É tarefa da filosofia e da teologia discernir, sob o equilíbrio refletido que se exprime nessas formulas de compromisso, a secreta discordância entre a lógica da superabundância e a lógica de equivalência. É também sua tarefa dizer que é somente no juízo moral em situação que esse equilíbrio instável pode ser instaurado e protegido. Podemos então afirmar de boa-fé e com a consciência tranquila que o projeto para exprimir esse equilíbrio na vida cotidiana, no plano individual, jurídico, social e político, é perfeitamente praticável. Diria inclusive que a incorporação tenaz, passo a passo, de um grau suplementar de compaixão e de generosidade em todos os nossos códigos - código penal e código de justiça social - constitui uma tarefa perfeitamente razoável, embora difícil e interminável (RICOEUR, 2012a, p. 33).

Ao final deste breve trajeto, já sabemos qual é a tarefa da filosofia da religião, que é refletir sobre a regeneração que o discurso da religião pode oferecer ao sujeito. Sabemos que o discurso filosófico e o religioso possuem problemáticas semelhantes, como a do mal, e estes discursos se encontram na ação. Sabemos a importância do discurso religioso para o discurso filosófico, qual seja, não o deixar cair na crueldade. Por fim, sabemos de outra coisa muito importante, a lógica do discurso filosófico, que é a da justiça, é condição de possibilidade para o discurso religioso.

\section{III}

Apresentemos mais alguns comentários para, com isso, analisarmos alguns trechos dos textos de filosofia da religião de Ricoeur. Primeiramente, temos que ter claro que nos textos de filosofia da religião de Ricoeur, ele não pretende resolver um problema, mas um chamado. Neste sentido, este pensamento não procede da filosofia, mas do lugar de onde provém tal chamamento, ou seja, da Palavra. Há uma distinção crucial para Ricoeur entre a resposta dada por um filósofo e aquela dada por um crente: “[...] responder para o filósofo, é resolver um problema. Responder, em face da palavra das Escrituras, é corresponder as proposições de sentido provenientes do dado bíblico" (RICOEUR, 2012a, p. 39).

[N]ão se deveria dizer, por exemplo, que a fé religiosa ou a teologia trazem respostas às perguntas feitas e não resolvidas pelo saber cientifico e filosófico; essa maneira de entender a ideia religiosa de resposta, seja em sua postura triunfalista, seja em sua postura modesta, até mesmo envergonhada, de uma fé tapa-buraco, no sentido denunciado por 
Bonhoffer, baseia-se em um desconhecimento da diferença de principio que distingue a relação epistemológica entre pergunta e resposta da relação especificamente religiosa entre chamado e resposta. A resposta religiosa é obediente, no sentido de uma escuta na qual é reconhecida, admitida, confessada a superioridade, entendamos a posição de Altura do chamado (RICOEUR, 1996b, p. 167).

Porém, isto não significa que a resposta do filósofo não pode ser relevante para o crente, nem que a resposta do crente possa ser irrelevante para o filósofo. O ponto principal a ser demarcado é a distinção, desde o início, entre a especulação de um e do outro. Com isso, seria errado pensar em uma filosofia-teológica, pois deixaríamos de compreender aquilo que os sistemas próprios nos têm a oferecer, tanto o da filosofia, quanto o da teologia. Assim, dois pontos podem ser acrescentados: (i) “[...] o chamamento a que a fé responde de múltiplas formas [...] nasce no meio da experiência e da linguagem humana com estruturas próprias [...]" (RICOEUR, 2012, p. 39) e (ii) essas estruturas originárias de experiência e de linguagem perpetuaram até nossos dias graças a um processo ininterrupto de transmissão e de interpretações que sempre implicou em mediações conceituais estranhas às expressões originais da fé de Israel e da Igreja primitiva cristã (RICOEUR, 2012a, p. 39-40). Estes dois pontos revelam duas coisas que são de fundamental importância tanto para filosofia, quanto para teologia, por um lado, a linguagem e, por outro lado, a tradição, que se perpetuam pela história. Esta semelhança faz com que haja um encontro, a filosofia da religião, porém, tal encontro não deve ser visto como negativo: "Não se trata de uma contaminação lamentável, muito menos de uma perversão, mas de um destino incontornável” (RICOEUR, 2012a, p. 40).

Sendo assim, já sabemos que a posição apontada por Ricoeur não é a de um teólogo, pois seu interesse não se volta para as teologias constituídas, isto é, para tradição teológica, mas para as expressões de fé bíblica mais primitivas, as quais ele pretende descrever fenomenologicamente (RICOEUR, 2012a, p. 42). Por consequência, não há espaço para uma atitude apologética por parte de nosso autor, isto é, sua análise não se encaixa nem em um estilo glorificante das Escrituras, nem um estilo de defesa desta. O foco dado é na experiência 
bíblica e sua linguagem. Mas, o que seria esta experiência bíblica, ou melhor, o que seria tal experiência religiosa? Nas palavras do próprio Ricoeur:

De minha parte, as formulações que me são mais familiares e mais próximas são as seguintes: sentimento de "absoluta dependência" para com uma criação que me precede, "cuidado último" no horizonte de todas as minhas preocupações, "confiança incondicional", que espera apesar de... tudo. São alguns sinônimos do que, na época contemporânea, foi chamado de fé. E todas as formulações que dela se podem dar atestam que fé, como tal, é um ato que não se deixa reduzir a nenhuma palavra, a nenhuma escritura. A esse título, ela marca o limite de toda hermenêutica, porque é a origem de toda interpretação (RICOEUR, 2012a, p. 46).

Em Leituras 3: Nas fronteiras da filosofia esclarece estas formulações:

Existem, com efeito, sentimentos e atitudes que podem ser chamados de "religiosos" que transgridem esse domínio da representação e, neste sentido, marcam a falta de domínio do sujeito em relação a todo império do sentido. Deram-se nomes a esses sentimentos: sentimento de dependência absoluta (Schleiemarcher); sentimento de confiança sem reservas, a despeito de tudo, a despeito do sofrimento e do mal (Barth e Bultmann); preocupação última (P. Tillich); sentimento a uma economia do dom, com a sua lógica de superabundância, irredutível à lógica da equivalência, como sugiro em meu ensaio Amour et Justice, sentimento de ser precedido na ordem da fala, do amor e da existência (Rosenzweig) (RICOEUR, 1996b, p. 165-166).

Deste modo, podemos dizer que fé, para Ricoeur, é um sentimento. Tal sentimento de pertencimento nasce da relação amorosa entre o divino e o sujeito. Com isso, podemos dizer que fé é um sentimento da mesma forma que dizemos que amor também é, dentro de todas as suas complicações próprias, para não cairmos em um certo sentimentalismo. A fé enquanto sentimento aponta para um novo horizonte fenomenológico, pois indica a busca de uma alteridade integral, e, assim como o amor, também mobiliza os afetos.

Esse sentimento, que consiste em maneiras de ser afetado absolutamente, desmente a incapacidade da fenomenologia abrir a intencionalidade da consciência para uma alteridade integral. A esses sentimentos e a essas afecções podemos localizar o título geral da prece e que se desdobram da queixa até o elogio, passando pela suplica e pelo pedido (RICOEUR, 1996b, p. 166). 
Como podemos notar, a fé é anterior à palavra e é origem de interpretação. Porém, sua investigação não pode ser anterior à linguagem, pelo contrário, devemos sempre investigar a experiência religiosa na linguagem. Assim, devemos ter claro que "[...] é sempre numa linguagem que se articula a experiência religiosa, quer a entendamos num sentido cognitivo, prático ou emocional” (RICOEUR, 2012a, p. 46). Neste sentido, a fé sempre é mediatizada, ou melhor, é sempre duplamente mediatizada, assim diz Ricoeur em seus fragmentos:

Minha relação com a pessoa da figura de Jesus é, assim, duplamente mediatizada: por textos canônicos, eles próprios carregados de interpretação, e por tradições de interpretação que fazem parte da herança cultural e da motivação profunda das minhas convicções. É nesse sentido que reconheço "aderir" à tradição evangélica reformada. Não há fé "imediata" (RICOEUR, 2012b, p. 63).

Mas como esta herança cultural e motivação profunda de convicções são fonte da interpretação por parte do religioso? A definição de cristianismo que Ricoeur propõe nos dá algumas pistas para uma resposta: “'Um acaso transformado em destino por uma opção continua': meu cristianismo" (RICOEUR, 2012b, p. 57). Segundo Victor Chaves de Souza, Paul Ricoeur quer apontar, com isso, que “[o] cristianismo se insere entre o destino e a convicção. É no sentido vivencial do assumir o destino que há a escolha constante" (SOUZA, 2017, p. 43). Assim, o cristão sempre se defronta com a figura de Cristo para assumir sua posição, sua interpretação. É possível perceber este posicionamento apontado no manuscrito de Ricoeur sobre a morte.

IV

Um dos textos de filosofia da religião de Ricoeur, ele inicia com o seguinte esquema:

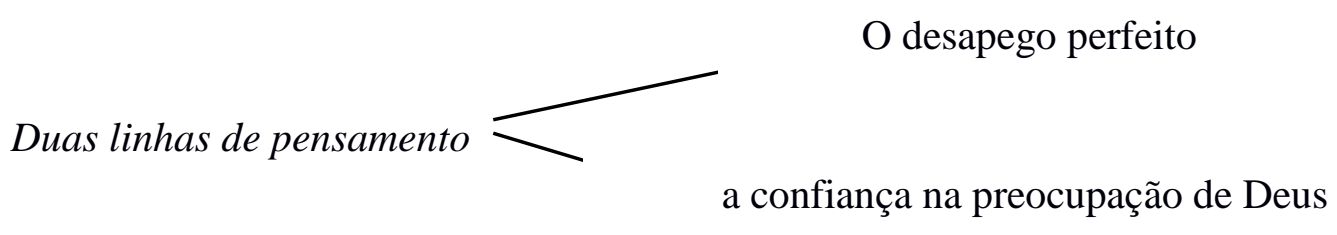

(RICOEUR, 2012b, p. 39) 
Temos aqui duas linhas de pensamento. Diante da segunda linha de pensamento, vemos a preocupação do cristão diante da morte: será que Deus se lembrará de mim? Pois, como o próprio Ricoeur indica, é mais do que natural a transição no sujeito religioso entre o presente do pensamento "Deus se lembra de mim", para o futuro "Deus se lembrará de mim" (RICOEUR, 2012b, p. 41). Por outro lado, a primeira linha de pensamento, expressada neste esquema, não aponta para filosofia, mas para o pensamento budista. Paul Ricoeur não recorre ao pensamento filosófico, pois reconhece que nesta problemática o budismo pode ser trazer resultados bem mais frutuosos: "Aqui o "budismo" pode ajudar, na medida em que em meu tema da atestação pode se ocultar uma resistência ao "desapego". Eu diria hoje: defensiva filosófica do ipse para uma ética da responsabilidade e da justiça. Renúncia ao ipse para uma preocupação para a morte" (RICOEUR, 2012b, p. 46).

Diante disso, podemos apontar três coisas:

I. Uma possível reflexão, por meio de uma filosofia da religião, do pensamento budista na hermenêutica cristã.

II. O quanto a reflexão da filosofia da religião por Ricoeur é independente de sua reflexão filosófica, isto é, não busca ser uma resposta para as questões levantadas em seus textos filosóficos, pois, em $O$ si-mesmo como outro, o filósofo francês se afasta do pensamento de Parfit, que tende ao budismo, por conta de suas consequências éticas (cf. RICOEUR, 2014a, p. 144).

III. Uma possível filosofia da religião no pensamento filosófico de Ricoeur, a partir da distinção filosófica entre ipse e idem.

Sobre a possibilidade de uma filosofia da religião a partir da distinção filosófica entre idem e ipse, a linha de pensamento do cristão faz com que levantemos outra questão, que é central para o pensamento de Ricoeur, o nomear Deus. Como já apontamos, a posição de 
Ricoeur não é a de um teólogo, mas de um filósofo que se abre para aquilo que o texto bíblico pode oferecer. Sendo assim, sua posição é a de um ouvinte da tradição cristã, por isso que o nomear Deus é tão fundamental. Segundo Souza, "Ricoeur suspende os esforços explicativos de questões como 'Deus existe', 'Deus é imutável', 'Deus é todo poderoso' e 'Deus é a causa primeira' por não assumir Deus como um objeto, um ser supremo, mas o pensa na experiência da percepção" (SOUZA, 2017, p. 84). Sendo assim, a nomeação de Deus só é possível por conta da tradição: "Se posso nomear Deus, por mais imperfeitamente que seja, é porque os textos que pregaram para mim já nomearam” (RICOEUR, 2012a, p. 47). O nomear Deus é o resultado da percepção que o sujeito tem de um Outro que realiza o chamado: “A prece virase ativamente para este Outro pelo qual a consciência é afetada no plano do sentimento. Em contrapartida, esse Outro que afeta é percebido como fonte de chamado ao qual a prece responde" (RICOEUR, 1996b, p. 166).

O nomear Deus é central, pois ele está no limite da linguagem e da experiência religiosa, do cristão e da pregação cristã. Aqui, também é onde podemos encontrar um diferencial que existe entre o texto bíblico e outros textos "clássicos":

Para utilizar outra linguagem, já evocada acima, direi que a fé bíblica tem seus "clássicos" que a distinguem, na opção cultural, de todos outros clássicos. E essa diferença é importante para a nossa investigação sobre o si, na medida em que os "clássicos" do judaísmo e do cristianismo diferem num ponto fundamental dos outros clássicos, desde os gregos até os modernos: enquanto estes alcançam seus leitores um a um sem autoridade outra que não a que estes consentem em lhe conferir, os "clássicos" que enfrentam a fé judaica e cristã o fazem através da autoridade que exercem sobre as comunidades que se colocam sob a regra - o cânone - desses textos. É assim que esses textos fundam a identidade das comunidades que os recebem e os interpretam (RICOEUR, 2012a, p. 47-48).

Assim, podemos compreender o motivo ao qual Ricoeur dedica sua reflexão ao cristianismo e não outra a religiosidade, pois é o cristianismo, com sua autoridade cultural, que está nas raízes culturais de nosso autor. Ele mesmo comenta este fato: "'Se o senhor fosse chinês, haveria pouca possibilidade que fosse cristão'. Certamente, mas vocês estão falando de outra pessoa, não de mim" (RICOEUR, 2102b, p. 57). Além disso, o estudo da religião só é possível ser feito através de alguma das religiões, “[...] a religião é como a própria 
linguagem, a qual só é realizada nas línguas. A religião não existe e não é realizada senão nas religiões" (RICOEUR, 1996b, p. 168). Essa é uma das conclusões que Ricoeur tira da situação de buscar estudar a religião através de uma religião:

A primeira delas é que é preciso desistir de compor uma fenomenologia do fenômeno religioso considerado em sua universalidade indivisível e que é preciso contentar-se, no início, em traçar as grandes linhas hermenêuticas de uma única religião. Eis por que, na análise que se segue, escolhi manterse nos limites das Escrituras judaicas e cristãs (RICOEUR, 1996b, p. 169).

A questão que fica é a seguinte: precisamos ser cristãos para estudarmos o cristianismo? Segundo a linha do pensamento de Ricoeur, podemos dizer que não é necessário, porém ajuda. Ou seja, um cientista da religião que, por exemplo, tem como alvo o estudo do cristianismo não precisa ser cristão, mas precisa de “[...] uma assunção imaginativa e simpática, compatível com o suspense [que o cristão tem] com o engajamento da fé" (RICOEUR, 1996b, p. 169).

Outra questão que se põe é esta: como podemos, enquanto filósofos, falar da religião? Como resposta a isto, Ricoeur traça a segunda consequência do seu posicionamento:

Segunda consequência: a hermenêutica interna a uma religião não pode pretender a se igualar a uma fenomenologia universal do fenômeno religioso senão a favor de uma extensão segunda, regida por um procedimento de transferência analogizante, conduzida aproximativamente, a partir do lugar em que está no início (RICOEUR, 1996b, p. 169).

Neste sentido, assim como só é possível pensar em uma filosofia da linguagem com base em filosofias da linguagem, podemos pensar em uma filosofia da religião tendo como base as filosofias da religião e a mesma imaginação e simpatia que apontamos como necessária ao cristianismo, também é necessária em relação às outras religiões, na busca de uma investigação que possamos chamar de filosofia da religião. Com isso, temos a terceira consequência proclamada por Ricoeur, esta inter-religiosidade como horizonte de toda investigação acerca de uma religião, isto é, a filosofia da religião como alvo das filosofias da religião (RICOEUR, 1996b, p. 170). 
Após esta pequena explanação acerca de sua reflexão sobre o cristianismo e suas consequências, Paul Ricoeur analisa a base textual do cristianismo, as Escrituras. O filósofo francês faz isso tendo como auxilio a obra The Great Code, de Northrop Frye. Frye é escolhido por Ricoeur, pois seus escritos tratam a Bíblia como "literatura", isto é,

[s]em ignorar as aquisições do método histórico-crítico, e desprezando as questões de autor, de fontes, de história da redação, de fidelidade à realidade histórica tal como podemos hoje procurar estabelecê-la, nós nos perguntamos simplesmente com base em suas estruturas textuais internas (RICOEUR, 2012a, p. 48).

Além deste ponto principal, dois pontos Ricoeur são destacados na análise de Frye: (i) a estranheza da linguagem bíblica em relação à nossa linguagem e (ii) a coerência interna que a Bíblia traz e seus próprios critérios de sentido (RICOEUR, 2012a, p. 49). Estas coisas são importantes, pois permitem que reflitamos sobre a relação que o sujeito pode ter em seu contato com as Escrituras. Assim, o sujeito possui uma total estranheza com a linguagem da Bíblia, por exemplo, o que significariam estes trechos metafóricos: "Iahweh é minha rocha e minha fortaleza" (BÍBLIA, Salmos 18, 3a); "Dize-lhe Jesus: 'Eu sou o Caminho, a Verdade, a Vida"” (BÍBLIA, João 14, 6a); "Enquanto comiam, Jesus tomou um pão e, tendo-o abençoado, partiu-o e, distribuindo-o aos discípulos disse: 'Tomai e comei, isto é meu corpo" (BÍBLIA, Mateus 26, 26). Para se aproximar do querigma, é necessário se aproximar da linguagem poética bíblica através de sua unidade imaginativa: "A unidade imaginativa (e não imaginária, notemos) da Bíblia é assegurado de forma muito mais decisiva pelo funcionamento de parte a parte tipológico dos significados bíblicos [...]” (RICOEUR, 2012b, p. 50). Ou seja, Frye reconhece na Bíblia uma rede ramificada de significados que muitas vezes se correspondem e que permitem uma leitura que vai de alto a baixo, de baixo a alto, e que permitem a decodificação poética de tais trechos. Temos, assim, apontadas por Ricoeur, associações tipológicas que nos guiam em meio à poesia bíblica, como entre as figuras de José e Jesus, entre o êxodo dos hebreus e a ressureição de Cristo, a lei do Sinai e a lei do Sermão da Montanha, ou, mais claramente, o Gênesis e o prólogo do Evangelho de São João (RICOEUR, 2012b, p. 50). Observemos este último exemplo. 
Em Gênesis, encontramos: "No princípio, Deus criou o céu e a terra. Ora, a terra estava vazia e vaga, as trevas cobriam o abismo, e um vento de Deus pairava sobre as águas" (BÍBLIA, Gênesis, 1, 1-2). Já no Evangelho de São João, encontramos a seguinte passagem:

No princípio era o Verbo /e o Verbo estava com Deus /e o Verbo era Deus. /No princípio, ele estava com Deus. /Tudo foi feito por meio dele /e sem ele nada foi feito. /O que foi feito nele era a vida, /e a vida era a luz dos homens; /e a luz brilha nas trevas, mas as trevas não a apreenderam (BÍBLIA, João 1, 1-5).

Ricoeur vê no pensamento de James Barr uma complementação ao pensamento de Frye, quando ele diz “[...] que na Bíblia os acontecimentos, os personagens, as instituições não se sucedem segundo um modo linear, em que o que sucede substituiria simplesmente o que precede, mas se acumulam e se reforçam mutuamente" (RICOEUR, 2012a, p. 51). Com isso, podemos dizer duas coisas: (i) A compreensão da poética bíblica se daria através das figuras que formariam uma espécie de "U”, ou seja, quanto mais eu compreendo o livro do Gêneses, mais eu compreenderia o Evangelho de São João e vice-versa; (ii) assim, por mais que há uma linguagem “estranha”, há uma autossuficiência no texto bíblico. Por isso, Paul Ricoeur pode afirmar que a Bíblia é um livro que o cristão pode fazer de Espelho:

Na medida em que se põe entre parênteses a eventual representação de acontecimentos históricos reais, e com ela o movimento centrífugo e referencial do texto que caracteriza a linguagem argumentativa e, ainda mais, a linguagem demonstrativa, que em nossa cultura recobriam e recalcaram a linguagem metafórica, a única relação importante com a realidade, num texto poético, não é nem natureza, como num livro de cosmologia, nem o desenrolar efetivo dos acontecimentos, como num livro de história, mas o poder de suscitar no ouvinte e no leitor o desejo de compreender a si mesmo à luz do Grande Código. Precisamente porque o texto não visa nenhum exterior, ele só tem a nós mesmos como exterior, nós mesmos que, recebendo o texto, nos assimilamos a ele e fazemos do Livro um Espelho. Nesse momento, a linguagem, por ética em si, se torna querigma para nós (RICOEUR, 2012a, p. 53).

Assim, podemos chegar a uma conclusão: por conta de seu caráter diferenciado, por não ter em vista nenhum exterior, a Bíblia é, segundo Paul Ricoeur, um livro privilegiado para a busca do si em se autoconhecer. Com isso, na Bíblia, o sujeito se reconhece, na nomeação de Deus, e, assim, se reconfigura, por isso, as Escrituras são como um Espelho. 
Duas observações acerca do texto bíblico devem ser feitas. A primeira observação é a seguinte: "Se alguma unidade pode ser reconhecida na Bíblia, é mais da ordem polifônica do que tipológica" (RICOEUR, 2012a, p. 54). Com isso, Paul Ricoeur quer deixar claro que o texto bíblico não possui os mesmos jogos de linguagem que os nossos jogos de linguagem, os jogos de linguagem do pensamento moderno, isto é, por mais que encontremos nomes como narrativas, prescrições, estas não são como nossas narrativas ou prescrições. Por isso, a unidade bíblica apresentada por Ricoeur através do pensamento de Frye é uma unidade polifônica e não uma unidade tipológica. Mas o que isso quer dizer? Quer dizer que Ricoeur reconhece uma unidade, o nomear Deus, em meio a uma multiplicidade tipológica da Bíblia, que vai além de narrativas, prescrições, entre outros gêneros literários. Para exemplificar isso, Paul Ricoeur afirma:

Numa perspectiva puramente narrativa, Deus é o meta-herói de uma metahistória, que engloba mitos de criação, lendas de patriarcas, uma epopeia de libertação, de errância e de conquistas, uma quase historiografia de monarcas e de reinos; de Deus, fala-se aqui na terceira pessoa, no sentido de um superagente (segunda conferência) ou de um superpersonagem (quinta conferência) (RICOEUR, 2012a, p. 56).

Tanto na segunda conferência, quanto na quinta conferência, de $O$ si-mesmo como outro, indicadas na citação, Ricoeur aponta o nomear de Deus em um nível que vai além do sujeito, isto é, enquanto os estudos de $O$ si-mesmo como outro indicam um si que é agente e que é personagem, a Bíblia aponta para um Deus que é superagente e superpersonagem. Com isso, o caminho filosófico auxilia-nos na percepção de um outro que não é como eu, na percepção de um agente que não é limitado como os outros agentes, de uma personagem que não é limitada como outras personagens. Assim, o sujeito se vê limitado perante o ilimitado, finito perante a infinitude, o que, por consequência, evita o pensamento do sujeito se pensar como soberano, o que contribui tanto para teologia, quanto para própria filosofia. Talvez, o primeiro passo desta filosofia da religião seja bíblico, pois, como afirma Meneses, "[...] a fé bíblica em sua precariedade pode contribuir a que a filosofia hermenêutica não recaia na distorção das filosofias auto-suficientes do cogito (MENESES, 2006, p. 64). No entanto, este 
primeiro passo não é um argumento, pois, como aponta Victor Chaves Souza, “[o] cristianismo oferece pensamento, mas não argumentação" (SOUZA, 2017, p. 223) e este pensamento só se torna argumentação pela filosofia. Ou seja, a filosofia da religião em Ricoeur não se dá através da descoberta de um sujeito que não é auto-suficiente, mas na argumentação em favor deste.

Paul Ricoeur dá outro exemplo de nomeação de Deus e este exemplo ele promete aprofundar:

Já nos escritos proféticos, Deus é significado como a voz do outro, por trás da voz do profeta, Deus se apresenta na primeira pessoa como aquele que se dirige ao profeta que fala na primeira pessoa. Voltarei a esse tema na minha última conferência, do ponto de vista da estrutura do envio aqui implicada. Limito-me hoje a frisar outro aspecto da situação, que Deus é nomeado em dupla primeira pessoa, como palavra de outro na palavra do profeta (RICOEUR, 2012a, p. 57).

Neste momento da análise, Paul Ricoeur está preocupado em apresentar a unidade polifônica que a nomeação de Deus apresenta. Ainda exploraremos outro momento dessa filosofia da religião, que se dá através desta voz, que é trazida pelo profeta e que se diz que é de Deus. O importante a ser percebido é que não estamos diante de uma ontoteologia, já que "[a] palavra Deus diz mais que a palavra Ser, porque esta pressupõe o contexto inteiro dos relatos, das profecias, das leis, dos escritos da sabedoria, dos Salmos, etc.” (RICOEUR, 2012a, p. 60). Por isso, temos que estar atentos para mais uma observação, a estrutura dialógica que a Bíblia apresenta.

A segunda observação é a seguinte: “O referente 'Deus', dizíamos, não é apenas indicador do pertencimento mútuo a formas originárias da fé, é também o indicador de seu inacabamento" (RICOEUR, 2012a, p. 65). Ao nomear Deus, temos uma "[...] feliz conjugação da exegese do tipo histórico-crítico e da teologia bíblica” (RICOEUR, 2012a, p. 54). Ou seja, ao mesmo tempo que buscamos nomear Deus através da nomeação dada historicamente, sabemos que estamos nomeando o inominável. Para abordar isso, Ricoeur encontra auxilio no texto de Claus Westermann, What Does the Old Testament Say About 
God?, para apresentar as diversas expressões relativas a Deus que estão presentes no Antigo

Testamento e que cada uma destas expressões requer uma contrapartida humana.

Quadro 1: Resposta do sujeito às expressões de Deus, segundo Claus Westermann

(RICOEUR, 2012a, p. 78)

\begin{tabular}{|c|c|}
\hline Expressão de Deus: & Resposta do sujeito a Ele: \\
\hline Deus que salva & uma confissão de louvor \\
\hline Deus que abençoa & uma alma que também abençoa \\
\hline Deus que pune & uma atitude de arrependimento e penitência \\
\hline
\end{tabular}

A única garantia que temos de que estamos diante de um único e mesmo Deus é sua fala a Moisés: "Eu sou aquele que é” (BÍBLIA, Êxodo 3, 1). Além disso, esta fala nos revela que estamos diante de um Deus que se comunica e se reserva, pois o seu nome "[...] o homem não pode verdadeiramente pronunciar, isto é, manter à mercê de sua linguagem" (RICOEUR, 2012a, p. 66). O Nome de Deus não é um nome que define. Segundo Northrop Frye, esta situação tem ecos nas parábolas do Novo Testamento, em que é apresentada uma realidade que escapa a qualquer descrição. É neste sentido que Ricoeur comenta:

Assim, o Antigo Testamento diz uma só coisa de Deus, a saber, que ele é Um. Todavia, essa afirmação tem duas vertentes: a do inominável: "Eu sou o primeiro, e eu sou o último" (Isaías 44, 6), mas também a unidade polifônica entre todos os Nomes de Deus: Deus é o mesmo, quer salve, quer abençoe, quer julgue, quer tenha piedade. A continuidade entre os dois Testamentos é assegurada sob esse aspecto pelo vínculo tipológico que os une. Do lado da manifestação do Nome, o relato da Ressurreição faz eco ao Exxodo; do lado da retirada do Nome, as expressões-limite sobre o reino de Deus nas parábolas de Jesus correspondem ao que podemos chamar retrospectivamente de expressões-limite do episódio da sarça ardente. A "novidade" do Novo Testamento por certo não é negável: ela se resume na 
função de centro que o poema de Cristo confere ao poema de Deus. Mas o impulso em direção ao centro é aquilo que, para uma leitura cristã, trabalha do interior a "unidade imaginativa" da Bíblia. O Novo Testamento identifica esse centro com a pessoa de Cristo (RICOEUR, 2012a, p. 70).

O ponto principal disto é que Cristo não abole as nomeações de Deus, muito menos a retirada do Nome. Ao contrário, Jesus Cristo intensifica isto com a ideia de Reino dos Céus. Com isso, "[...] o leitor da Bíblia, diremos mais uma vez com Northrop Frye, é finalmente convidado a se identificar no Livro, que procede por sua vez da identificação metafórica entre a palavra de Deus e a pessoa de Cristo" (RICOEUR, 2012a, p. 70-71). Ou seja, o leitor da Bíblia é convidado a ouvir a Palavra de Deus, ou melhor, a voz do Outro, e ver seu reflexo Nela.

\section{VI}

Em O si “mandatado”. Na escola dos relatos da vocação profética, Paul Ricoeur escolhe a figura do si respondente, que é configurada a partir dos relatos de vocação profética (RICOEUR, 2012a, p. 77). Nosso autor escolhe os relatos das vocações proféticas, pois em tais relatos encontramos uma resposta “[...] estritamente pessoal” (RICOEUR, 2012a, p. 78). Com isso, a questão posta é a seguinte: como este si, chamado a ser profeta, responde ao seu chamamento?

Paul Ricoeur divide a estrutura desta resposta em três fases:

$1^{\circ}$. A confrontação de Deus com o profeta. Antes de tudo, é demarcado nas Escrituras a relação desproporcional que existe entre o "Eu" que chama e o "eu" que é chamado.

$2^{\circ}$. Deus se apresenta como fundação e autenticação do profeta.

$3^{\circ}$. Deus envia e este envio sempre se dá no singular.

Segundo Ricoeur, esta estrutura está clara, por exemplo, na vocação de Moisés (BÍBLIA, Êxodo 3, 1-15), Jeremiais (BÍBLIA, Jeremias 1, 1-19) e Ezequiel (BÍBLIA, 
Ezequiel 2, 1-10). No entanto, esta estrutura de resposta dada pelos profetas, segundo Ricoeur, adquire um novo paradigma no Novo Testamento, isto é claro no texto de São Paulo: "E nós todos que, com a face descoberta, refletimos como num espelho a glória do Senhor, somos transfigurados nessa mesma imagem, cada vez mais resplandecente, pela ação do Senhor, que é Espírito" (BÍBLIA, 2 Coríntios 3, 18).

Ao comentar tal trecho paulino, Ricoeur afirma:

Ele forja assim a metáfora central do si cristão como cristomorfa, isto é, a imagem da imagem por excelência. Uma corrente de glória, se ouso dizer - de glória descendente, cumpre precisar -, se forma assim: glória de Deus, glória de Cristo, glória do cristão. No fim da corrente, que a meditação faz remontar à sua origem, o si cristomorfo é ao mesmo tempo plenamente dependente e plenamente consistente: imagem "cada vez mais gloriosa", segundo o apostolo (RICOEUR, 2012a, p. 87).

Estas metáforas, as do Antigo Testamento e as do Novo Testamento, são refletidos, segundo nosso autor, nos livros de espiritualidade centrados na imitação de Cristo (imitatio Christi) e que tem grande marca na história da filosofia através da figura do "mestre interior", apresentada por Santo Agostinho. A grande descoberta de Santo Agostinho é a do "ensinamento interior", isto é, o sujeito ao encontrar com a luz deve continuar itinerante, pois esta luz não substitui a figura do mestre e a relação de discípulo-mestre não é uma relação intercambiável, por isso, na estrutura profética a primeira fase do relato é a da desproporção (RICOEUR, 2012a, p. 85-92). Sendo assim, conseguimos chegar onde achamos que é possível encontrar uma originalidade de Ricoeur no campo da filosofia da religião, que é a atualização da reflexão sobre esta "luz" que aparece para o sujeito consciente. Assim o próprio Ricoeur afirma:

A consciência é antes de tudo a atestação de que posso ser eu mesmo. Essa atestação ecoa como um chamamento de si a si mesmo, na medida em que esse poder ser si mesmo é frágil, vulnerável, geralmente perdido no anonimato. A acusação própria da "má" consciência é uma determinação secundária, mas necessária. Ela se prende da seguinte maneira à função da atestação da consciência. A consciência me diz que entre os meus possíveis mais próximos, encontro em mim a capacidade e a exigência de distinguir o bem do mal, capacidade de todo formal, no sentido que cabe à experiência cotidiana comum lhe dar conteúdo. $\mathrm{O}$ essencial aqui é que a exigência de 
distinguir o bem do mal na ação - digamos a exigência da justiça - está originalmente ligada à capacidade de emitir tal juízo. A atestação incide precisamente sobre esse vínculo original entre exigência e capacidade. Talvez o sentido de Schuld é que preceda a "má" consciência. Ela não é, como tal, "má" consciência mas sim possibilidade da "má" consciência, arraigada na capacidade da crisis. Nesse sentido, o estar-em-dívida, sem já ser culpa, é abertura prévia à alternativa à qual toda ação é submetida, a de ser ou boa, ou má; Tal abertura à alternativa não quer dizer neutralidade; mas, muito pelo contrário, obrigação de decidir entre uma avaliação e outra pelo juízo. O que a consciência atesta é que o que eu devo nesse sentido puramente formal - a saber, distinguir o bem do mal -, eu posso e todo homem como eu pode. É um dos significados que é possível atribuir ao prólogo do Evangelho de João. "No Verbo estava a luz verdadeira, que ilumina a todo homem" (RICOEUR, 2012a, p. 113 -114).

Ora, se a grande contribuição de Ricoeur para tradição filosófica hermenêutica se deu através de uma hermenêutica reflexiva, a mesma reflexividade não seria encontrada em suas contribuições acerca das temáticas religiosas que ele analisou? Neste sentido, Ricoeur é um agostiniano pós-kantiano. Agostiniano, pois, assim como Agostinho, encontra na infinitude caminhos possíveis para se pensar a finitude. Pós-kantiano, pois a ordem se inverte, este caminho da infinitude só é encontrado por meio de uma análise que qualquer convicção só é conseguida após tortuosas críticas, ou melhor, suspeitas. É uma filosofia da religião que surge a partir de um sujeito que se reconhece na imagem fornecida pelo espelho das Escrituras, como já dissemos neste artigo. Deste modo, a filosofia da religião para Ricoeur, como na citação acima, se dá sempre na "última linha" e como um significado de esperança aberto pela tradição. Esta esperança é de um sujeito que é agente e padecente. Esta filosofia da religião é de um filósofo que é hermenêutico para ser reflexivo. Portanto, a contribuição de Ricoeur para filosofia da religião se dá através de uma filosofia hermenêutica reflexiva da religião, com os termos exatamente nesta ordem, já que a religião vem por último. Mas, ser o último não significa ser o menos importante. Se pararmos para pensar, alguém importante já disse: "Os últimos serão os primeiros!".

\section{Referências:}

BÍBLIA de Jerusalém. São Paulo: Edições Paulinas, 1985. 2366 p. 
CAMÕES, Luís de. Sonetos. Disponível em:

$<<$ http://www.dominiopublico.gov.br/download/texto/bv000164.pdf $>>$. Último acesso em 08 jan. 2020.

GRECO, Carlo. A experiência religiosa: essência, valor, verdade - um roteiro de filosofia da religião. Tradução: Alda da Anunciação Machado. São Paulo: Loyola, 2009. 255 p.

MENESES, Paulo. Introdução. In. RICOEUR, Paul; A hermenêutica bíblica. São Paulo: Loyola, 2006. p. 1-74.

RICOEUR, Paul. A Crítica e a Convicção. Tradução: António Hall. Lisboa: Edições 70, 1995. 254 p. (Biblioteca de filosofia contemporânea).

RICOEUR, Paul. Leituras 2: a região dos filósofos. Tradução: Marcelo Perini e Nicolás Nymi Campanário. São Paulo: Loyola, 1996a. 343 p.

RICOEUR, Paul. Leituras 3: nas fronteiras da filosofia. Tradução: Nicolás Nymi Campanário. São Paulo: Loyola, 1996b. 205 p.

RICOEUR, Paul. Amor e justiça. Tradução: Eduardo Brandão. São Paulo: WMF Martins Fontes, 2012a. 114 p.

RICOEUR, Paul. Vivo até a morte. Tradução: Eduardo Brandão. São Paulo: WMF Martins Fontes, 2012b. 97 p.

SOUZA, Vitor Chaves de. A dobra da religião em Paul Ricoeur. Santo André: Kapenke, 2017. 459 p. 